\title{
Teachers Training for the Use of Digital Technologies
}

\author{
Danielle Aparecida do Nascimento dos Santos", Elisa Tomoe Moriya Schlünzen, Klaus Schlünzen Junior \\ Faculty of Science and Technology, Sao Paulo State University, Brazil
}

Copyright $\bigcirc 2016$ by authors, all rights reserved. Authors agree that this article remains permanently open access under the terms of the Creative Commons Attribution License 4.0 International License

\begin{abstract}
The doctoral research described in this article was developed in the context of a Licensure course in Pedagogy offered by two Public Universities of the São Paulo State, from 2010 to 2013. The purpose was to analyze how the teacher training program was established, aiming to the teaching of inclusive education fundamentals in a perspective of using Digital Information and Communication Technologies in a Constructionist, Contextualized and Meaningful approach. Through a qualitative research approach of the intervention type, it was designed, implemented, monitored, developed and evaluated by the Articulating Axis of Inclusive and Special Education proposed in the Licensure hybrid course in Pedagogy of the Virtual University of São Paulo State and the São Paulo State University Júlio de Mesquita Filho. Theoretical, methodological and practical frameworks that supported the organization of this research were related to the problematization of teacher training regarding School Inclusion, Comprehension of Curriculum, and the use of technologies in Education. The Axis was structured in five (5) blocks of 24 (twenty four) hours per week, having as proposition, the studies and practical activities about experienced aspects of the common school and, the use of technologies. The organization and analysis of data collected through questionnaires, reflective memorial, discussion forums and portfolios indicates the relevance that the role of this axis played in the conceptions of teachers-students regarding Inclusion policies and its application in school contexts linked to the use of technologies in a Constructionist, Contextualized and Meaningful approach. The results indicate the importance of contextualized training, which assign meaning to theoretical frameworks and articulate daily teacher practices.
\end{abstract}

Keywords Teacher Training, Digital Technologies, Inclusion

\section{Introduction "Contextualization, History and Origin of the Survey"}

"Teachers live difficult and paradoxical times. Despite criticisms and distrust in relation to their professional skills it is required of them almost everything" [1] (p.12).
The statement from one of the most representative authors in education and teacher training nowadays can be taken as the emblem for the past few years, regarding the referential and theoretical constructions and practices on the problem of teacher education. It makes us think that this profession, target of the most diverse criticism, and motto for the development of educational policies, requires, besides being rethought and reflected, having as parameters the social, cultural and technological changes available in the age of information and knowledge.

What does the current school expect of teacher and student? What are its paradigms? Whom this school serves? Who are these teachers and students that currently attend the school environment? These and other questions refer to the situation that, considering the several means of obtaining information, the teacher is no longer the only existing source of information, but is also an essential element for the construction of student's knowledge. This is because only the teacher can help them to prepare themselves for the systematization and formalization of concepts, attitudes and procedures, through a practice that allows questioning, doubt, collectivity and stimuli and articulation of experiences with school concepts, through the valorization of diversity existing in school.

The new paradigms about teachers education and school bring to the bulge of academy discussions, dilemmas as the use of Information and Communication Digital Technologies (ICDT) in Education and School Inclusion, both axes that raise "the carpet" of school, bringing the demands of quality education for ALL, including people with disabilities, global developmental disorders and high skills/giftedness. These students are considered by the National Policy of Special Education in the Perspective of Inclusive Education [2], as Students Target Audience of Special Education (EstudantesPúblico-Alvo da Educação Especial - EPAEE).

In this sense, teachers and school have to transform themselves, remodeling the school in a place of humanization, once the networked knowledge emerges as the conductor wire of that process and gain a broader meaning, transforming the teachers also in apprentices. Therefore, they have to make themselves facing the unknown, identifying their weaknesses and developing strategies for overcoming practical difficulties regarding the demands above mentioned. In this sense, the construction of 
knowledge becomes collective; having as parameter the teaching, since learning is considered as an individual activity, regulated by the subject himself. There must be, in teacher education, the development of practices lead by these subjects, having as the common thread of their own experience and at school, a collective experience, where being and doing are activities shared by all, so that everyone can grow with their peers and build knowledge according to their own time, pace and learning process.

According with Hernandez [3], is necessary for the teachers to be in a continuous process of training and transformation of their practice, reworking the knowledge they use, with the purpose of building at school a space not only of work, but also for research, action and formation. The school has to promote actions of teacher training in-service, that is, in which teacher intervention is essential to the developmental process of student and where he has a gaining of awareness and interprets his reality from his own actions.

The São Paulo State University "Julio de Mesquita Filho" (Universidade Estadual Paulista - UNESP), guided in these assumptions, indicates in its Institutional Development Plan, the mission and commitment to exercise its social function and promote a "professional education committed with life quality, technological innovation, sustainable society, social equity, human rights and democratic participation" [4] (p. $01)$. Therefore, in partnership with the Virtual University of São Paulo State ${ }^{1}$ (Univesp), since 2008, the Training Program for Teachers in-service was developed to act in childhood education, in the initial series of primary school and in the management of school unit, through the Licensure course in Pedagogy.

The first class of the Licensure course offered by Univesp/Unesp began in March 2010, with the offer of 1.350 (one thousand three hundred and fifty) vacancies, being distributed in 22 (twenty-two) of the university campuses and 27 (twenty-seven) classes of up to 50 learners. The course was developed under the Univesp program and, therefore, blended learning, providing initial education and being directed to teachers in-service in the magisterium, with training in other licensure. It was organized in modules/disciplines and distributed in blocks from large training areas (General Training, Didactics of Contents and School Management), in a total amount of 3.390 (three thousand, three hundred and ninety) hours.

This proposal of initial training, in-service, was designed for teachers to be aware and place the learning needs of the students, who they assist, as the center of their practice, opening spaces for cooperation, dialogue, creativity and exercise of critical thinking using ICDT as resources to support teaching. Teaching methodology of the course

1 Univesp has focus on the expansion of higher education public, free and with quality of São Paulo State, expanding the number and geographical coverage of vacancies offered in blended courses of extension, graduation and post-graduation, in partnership with USP, Unicamp and Unesp, with the Paula Souza State Center of Technological Education (Ceeteps) and the Padre Anchieta Foundation (FPA). includes research on the Internet, use of interactive medias, printed materials and pedagogical experiences in face-to-face classrooms and virtual classrooms, available in a Virtual Learning Environment (VLE), besides video classes and TV programs coordinated by TV Cultura used in a perspective of Distance Education (DE).

According to Unesco, the challenge of DE is to be integrated to the educational structure, improving the quality, effectiveness and efficiency of education and training, promoting wide and diversified educational opportunities. In this sense, it is important to consider the researches in this area that aim to contribute with the development of qualified training actions in this modality, which meets the assumptions of training in action, committed with the school reality and with the collective construction of lifelong learning spaces.

The project "Educators Training: Commitment with Special Education in the Perspective of Inclusive Education", theme of this doctoral research, with duration from August 2010 to August 2014, had as main goal the development, implementation and evaluation of the Articulating Axis of Inclusive and Special Education included in the curricular component of the Licensure course in Pedagogy of Unesp/Univesp. This research was developed in the context of the Support Program for Special Education (PROESP), in the Post-Graduation Program of Education of the Faculty of Science and Technology (FCT)/Unesp, in Presidente Prudente (São Paulo). Theoretical perspectives and practices of this study have considered the universe of information about the construction of this axis and, its implications in the understanding of course learners (teachers in-service) about their own practice regarding school inclusion, special education and the use of ICDT in this process.

\section{Development}

The research project was registered in the Research Ethics Committee with the title "Teachers training for the use of digital educational resources: perspectives for an inclusive school" (CAAE: 02395412.2.0000.5402). The elements considered for the construction of the Articulating Axis of Inclusive and Special Education were the participants' productions, such as: interactions in Discussion Forums, individual productions posted on Individual Portfolios and collective productions, posted at the Portfolio of Groups. The focus of the analysis was the environments of all classes, being highlighted the productions related to the thematic axes of this paper, regarding their conceptions about technologies, practices and inclusion.

\section{"The Construction of the Articulating Axis of Inclusive and Special Education"}

The Licensure Course in Pedagogy Blended Learning of Univesp/Unesp, is prepared by specialists in Education and Distance Education and has as premise the incorporation of ICDT in the practice of teachers in training, aiming to the construction of contextualized and significant learning 
environments. The course graduated 1005 (one thousand and five) learners (teachers in training), according to information available on the Edutec Portal. ${ }^{2}$

Taking as basis the construction assumptions of contextualized and significant learning environments, we rely on Schlünzen [5], to establish connections between the approach desired by the course, and the constructionist approach of teaching and learning. According to the author, in this approach the technology is used in order that the student solves problems, formalizing, clarifying and building knowledge, through technological resources. Therefore, he plays the role of who uses technology to set out his ideas, within a context that he knows, instead of being taught by a machine, producing something tangible and meaningful.

In relation to Distance Education, Valente [6] complements this perspective asserting that, in teacher online training in a constructionist approach, the participant's posture may be such that he begins to modify his attitudes, becoming an agent of search and construction of knowledge and co-author of his personal and professional learning.

In this sense, the course program was developed considering $60 \%$ of the course load in distance activities and, $40 \%$ on campus meetings, being, the course content, available in three languages (printed, television and online). The face-to-face moments counted with the display of programs developed by the Padre Anchieta Foundation digital channel, Univesp TV, through the programming built under the coordination of Specialist Teachers, who are responsible for the preparation of the course content. In these face-to-face moments, the classes have the support of 02 (two) tutors, who are called Discipline Advisors (DA) and are responsible for organizing the dynamics of classes and monitor the activities that should be carried out online. During the week are held 02 (two) meetings, and the rest of the activities are available at the VLE of each class, separated by disciplines.

The curricular matrix of the course is composed by Articulating Axes, understood as generator center through which are discussed theories and practices in accordance with the disciplines of three large blocks of contents. We consider this as a differentiated characteristic of the course curriculum, since in researches carried out from the curriculum matrices of other initial training courses in Brazil, no records were found of a similar curriculum organization. The curriculum structure, organized by disciplines and supported by articulating axes, brings to the center of practice, the conversion characteristic in a learning environment contextualized and significant, since through these axes, it may be possible to address not only the training content, but alternate the built of knowledge with the practices experienced in this process of initial and in-service training.

2 All information about the Course of Licensure in Pedagogy Blended Learning of Univesp/Unesp is available at the Edutec Portal - Education and Technology of Unesp, avaliable at:

http://edutec.unesp.br/index.php?option=com content\&view=article\&id=1 2\&Itemid=131\&lang=pt_br, accessed on 25 Jul 2013.
According with Zabala [7] this conception can allow to understand the complexity of teaching and learning processes, once teaching can help to establish essential and not arbitrary bonds, between the content learned and the prior knowledge of the teacher in training. Morin [8] helps us to think about this affirmative, putting that in opposition to this conception, there is an ever more profound inadequacy among knowledges, which are separated, fragmented and compartmentalized in disciplines, while there are realities and problems "increasingly multidisciplinary, transversal, multidimensional, transnational, global, planetary (p. 13)".

Training has to be thought where the active and protagonist role of teacher, who is in an initial training process, does not counteract his active role, as a teacher who acts in the classroom or in the school management. Therewith, having the articulating axes as curriculum components that provide experience and practice, the nature of the pedagogical intervention of the course can establish parameters on which the intellectual activity of this teacher is used to compose moments of balance, imbalance and rebalancing, considering his personal characteristics of interpersonal relation and of social insertion.

To this end, the Articulating Axis of Inclusive and Special Education was composed of 120 hours/classes and, prepared in accordance with the assumptions of the Political-Pedagogical Project. It was designed to contribute so that these teachers knew and reflected on the pedagogical and technological resources necessary in order to be able to develop a pedagogical work that offered to children the necessary conditions so that they can build a world oriented by solidarity and respect of differences [9].

The main challenges of this Articulating Axis relate to the understanding and experience of Special and Inclusive Education. In accordance with Mantoan [10], if we want the school to be inclusive, it is urgent to redefine its plans for the constitution of an education aimed to global citizenship, complete, free of prejudice and one that recognizes and appreciates the differences. However, school has created many arguments to resist inclusion, arguments that reflect the school inability, as a whole, to act in the face of complexity, diversity and of what is real in human beings and human groups.

The reflection and debate on Inclusive School have as base the historical path of struggles and achievements of EPAEE, especially in the last decade of the twentieth century, where the Brazilian educational policies began to dedicate greater attention to those in need of a Specialized Educational Service (Atendimento Educacional Especializado-AEE). Such reflections and discussions have brought to the center of discussions on education, the issue of teacher training to meet the students with Special Education profile. Therefore, the international movements of integration and school inclusion of students with some kinds of disability, in a more tangible way from the decade of 1990, have influenced the educational policies in the area of Special Education in several countries, among which, Brazil 
as well.

This process had as apex the orientation of the National Directives for the Special Education in the country's basic education [11]. It has determined the prioritization of school education of students with disabilities in regular education system, provided for by the Law of Directives and Bases of National Education - LDBEN, no. 9.394 of 1996 [12] and already assured by the Federal Constitution [13]. After the promulgation of the LDBEN 9394/96, other documents have emerged, seeking to complement what remained as insufficient or dubious in the educational legislation, for example, the Resolution 02/2001 of the CNE/CEB [14].

The Brazilian legislation, through the LDBEN 9394/96 and, more recently, through the Decree no. 6.571/08, among others, presents itself as a milestone, quite significant in the process of the country's school inclusion. It recommends the implementation of Specialized Educational Service (AEE), in public schools to the Students Target Audience of Special Education (EPAEE), starting at Basic Education (childhood education, elementary and middle school) to Higher Education.

In this perspective, Delors [15] asserts that the school has to introduce the real world for the individual, including its complexities and disturbances, as well as indicate resources and paths to follow through and recognize this world. In this way, an inclusive education can guarantee to every person the right to study and, above all, to learn. However, to this, it is necessary for the school to keep in mind that everyone have the right to study and, therefore, open itself to the possibilities of partnerships so that this right does not constitute in a burden or an impossible task, being instead, a learning opportunity for all.

With this, the proposal of initial training in-service, herein described, gains a transformation prospect, since, according to Santos [16], this perspective of inclusive school makes teachers to have responsibility not only of their fragmented field of knowledge but also knowledges that emerge in the school routine. Likewise, learning becomes a part of a much larger context than the one of scientific contents, and it is not necessary to leave the field of knowledge to enter into another, without connecting them; everything can be worked in a unified manner, since this is a difficult and complex task, and the teacher has to think in multi-dimensional problems [8]. The Articulating Axis of Inclusive and Special Education was drawn up to meet the following objectives:

- Develop knowledges on School Inclusion and Special Education articulated to specific knowledges of teaching methodologies;

- Study the prospects of School Inclusion and Special Education seeking to identify their characteristics, differences and similarities;

- Analyze laws and decrees that configure the teaching approaches; Identify what are the practices and resources that can be used in the inclusive perspective for the development of EPAEE's skills;

- Analyze possibilities of professional performance, using as starting point the Constructionist,
Contextualized and Significant Environment and the Work with Projects.

The proposal, supported in the prospects of Zabala [7], has brought to the center of discussions about the didactic of contents, the work with factual, conceptual, procedural and attitudinal contents. The author defines the factual contents as those that encompass the knowledge of facts, situations, data and concrete and singular phenomena, related to problems that arise of daily life. The conceptual contents as those that include concepts, that is, phenomena or situations expressed in the knowledge historically constructed by humanity. The procedural contents as the coordinated actions for performing tasks as: read, draw, observe, calculate, classify, translate, and collaborate, among others. Lastly, the attitudinal contents involve values, attitudes, rules, standards and cultures.

The Articulating Axis was drawn up in order to ensure the quality of teachers training, contributing thus to the construction of a quality school for all, reflecting on these aspects that, certainly, are part of the professional experience of these teachers.

In addition, since it is a program of initial training of teachers in-service, mediatized by technologies, the proposal had also, as a premise, the use of ICDT in pedagogical action, implying in setting goals for:

- the use of ICDT in the university environment for dissemination, optimization and generation of scientific knowledge and,

- as elements of an innovative proposal, which seeks to apply various usage possibilities of these resources so that teachers really use them in the school environment.

The 120 hours (one hundred twenty hours) of the Articulating Axis were diluted in five blocks of $24 \mathrm{~h} / \mathrm{a}$ (twenty four class-hours) weekly, whose activities were realized in 2011 and 2012. The disciplines had the following Contents: General Didactic, Didactics of Literacy, Didactics of Portuguese Language and Literature, Didactics of Arts, Didactics of Physical Education, Didactics of Mathematics, Didactics of History, Didactics of Geography, Didactics of Science and Health and, Didactics of Libras (Brazilian Sign Language).

To list the knowledge about the history of School Inclusion and Special Education in Brazil and worldwide, considering their characteristics, differences, similarities, action policies and possibilities of professional activity, the axis elaboration began in the year 2009, considering the presentation need of their contents under the form of representative blocks of each characteristic covered by the areas of didactics. The following content blocks of the Axis had as basis the achievement of activities on campus and at distance, at the Virtual Learning Environment (VLE) TelEduc, situated in the Edutec portal (as the example in Figure 1), as well as the weekly distribution of these concepts among the disciplines of Didactics of Content. 


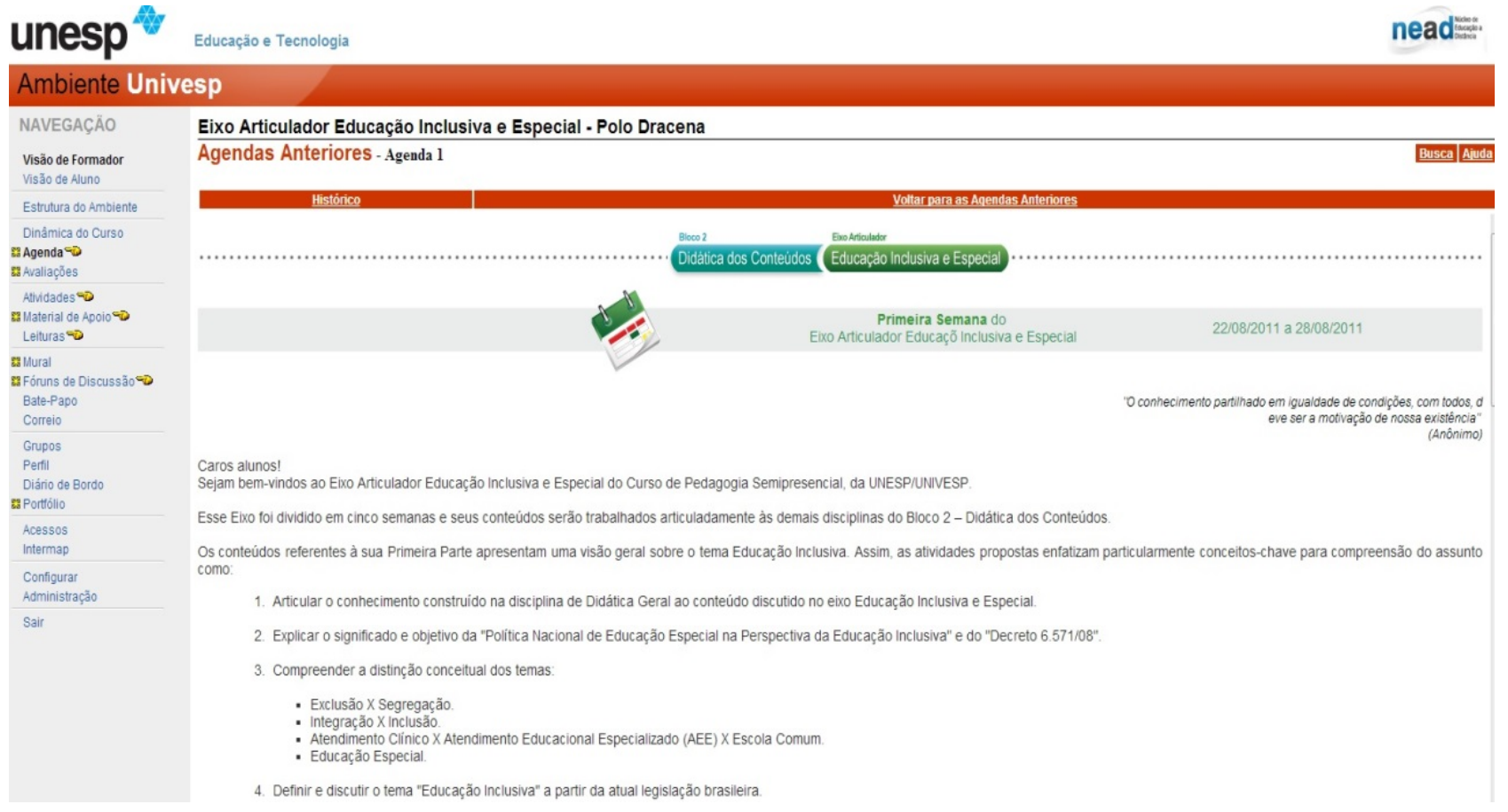

Figure 1. First agenda of activities from the Articulating Axis of Inclusive and Special Education (AVA - Campus of Dracena).

1) Policy of Inclusive Education and Curricular Adaptations;

2) Work with Projects and Presentation of ICDT and Educational Objects;

3) ICDT for the work with specific contents of Didactics of Content;

4) Elaboration and application of Inclusive Teaching Plans (Planos de Ensino Inclusivos - PEI) and articulated Projects to the different contents of Didactics of Content;

Considering its distribution in blocks, the methodological dynamic of the Articulating Axis was organized in the sense of integrating theory and practice, through readings, summaries and discussion of requested texts; surveying and experience of proposed activities by different sources, including the valuation of experiences built by students/teachers. It includes the accomplishment of surveys with teaching institutions so that students have contact with reality and can prepare themselves for the pedagogical work; use of platform tools from virtual learning, the organization and development of work in groups (Inclusive Teaching Plans - PEI) and lastly, understanding and mastery of the content worked.

Zabala [7] asserts that it is not possible to teach without starting from an idea of how learning is produced, considering that, it depends on singular characteristics of each one of the apprentices. Therefore, the pedagogical approach of initial training in-service gives attention to the diversity of learners as a structuring axis.

\section{"The implementation of the Articulating Axis of Inclusive and Special Education"}

Regarding the construction prospects of the Axis, the first part was organized with the purpose of presenting the contents and key concepts for understanding its theme, articulated with the knowledge built in the discipline of General Didactics. Activities were organized to start a collective drafting of an Inclusive Teaching Plan (PEI) having as basis the contents studied along the General Didactics discipline. Learners were stimulated to take advantage of the knowledges built in this discipline for the organization of a collective PEI, based on a specific roadmap. This activity, linked with other activities of: participative dialogue, reading, presentation of Educational Policies (Legal Milestones) and resolution of a questionnaire, based on the articulation of ideas in the face of different realities, presented by each member of the composed groups, taking in consideration the professional performance area.

The presentation of policies has activated the prior knowledge of teachers, and has brought to the center of discussions their expectations about the elaboration of practical proposals, beyond the knowledge of legislation, as explains the testimony from the student J.R.P. of Sorocaba's Campus, in the Discussion Forum 01 "Special education in the perspective of inclusive education: limits and possibilities":

It is unquestioned that the inclusion also happens in schools. We already have laws sufficient to regulate and put into practice the inclusion in public schools, and the Teacher must have knowledge about public policies so that may have subsidies to guide their actions. The great expectation for the Articulating Axis of Inclusive and Special Education, perhaps is to show directions, paths that should guide the practice of teaching with PD learners. (J.R.P., 02 Sep. 2011)

Complementing this expectation, the student C.V.R.F. of 
Tupã's Campus, adds:

Public policies are very important and, much progress has been made in this regard, however teacher most often is not informed about it, which hinders the pedagogical practice, we should all be informed about the laws that govern some segment, but not always we are, mainly for lack of time, sometimes for lack of interest. There should be a more practical link where occurs this exchange of significant information to the teacher work. (C.V.R.F., 15 Mar. 2012)

Thereby, in this first moment was necessary to clarify that the focus of all practical activities of the axis should be the students, their needs and context. In addition, the initial guidance was that they could articulate their specific knowledge for the elaboration of a PEI that valued the differences of their students.

Here we note the connection of the dynamic established in the axis with the factual contents, defined by Zabala [7]. Such knowledges posed by learners indicate the information and problems that arise in daily and professional life, activating their memories expressed in an original way.

The second part was proposed right after the Discipline of Literacy Didactic Content. In this moment, the activities and materials were organized considering the application of concepts learned on Literacy, presuming individual and collective work among students, whether in physical meetings, or at the VLE. Additionally, it was proposed a debate that dealt specifically of the PEI elaboration, started in the first week. The purpose of the second week of the Axis was to articulate the plans already made for a collective presentation. This strategy allowed the course students to have the opportunity to develop even better the capacity to plan, select and apply, in the school context and classroom, the pedagogical and technological resources, with a view to the process of EPAEE inclusion.

To evaluate the motivation and learning generated by this strategy, it was proposed a Reflexive Memorial, where the learners carried out a self-assessment of the entire route (process) lived along the Axis. Thereby they could return to their annotations, especially the developed activities; studies of texts and videos; interaction with peers and with Discipline Advisor; the Inclusive Teaching Plan - PEI. The roadmap of Memorial considered questions that would lead them to reflect as person and professional, aiming to stimulate a reflective process in the course of the Axis.

In these reflections, the student A.T.L. of the Campus São Paulo 1 indicates that:

Initially, it is necessary to understand that to include should not be the attitude of minimize the curriculum to facilitate the learning of children, but rather to think the child learning process in a way that planning is thought to stimulate the development of skills and capabilities so that children can gradually reach and overcome. (A.T.L., 18 Jun. 2012)

This reflection relates to the perspectives of Mantoan [10], who states that certainly, there is not a general rule for building the school that we want, but we can get closer to it, if we face a transformation and inversion of values. The student has to be in the center of practices and the school has to be adapted to reality, abolishing all that refers to a curriculum organization where there is an ideal of student. Prospects as the one of this student indicate that, through the reflections in this training process, there is already a tendency of teachers in thinking about reorganizing the school and its practice, according to a logic of justice and equal opportunities and, overcoming the limitations imposed by the disability.

In continuity to these reflections and practices, in the third part of the Axis, the activities were drawn up to offer grounds for the use of strategies and resources directed toward the construction and implementation of inclusive teaching practices, articulating them to the contents worked in disciplines of Contents and Didactics of the Portuguese Language and Literature and Arts. The perspective and analysis of ICDT use was introduced in the inclusive process. Learners have experienced an Educational Object (EO) called "Scrapbook" ${ }^{3}$ and had the opportunity to explore the software in the face-to-face class. The goal was to identify possibilities for its use in the process of teaching and learning of school content related to curriculum components of Portuguese Language, Literature and Arts, seeking to reflect on the importance of allowing the construction of knowledge from the self-image by the students and teachers themselves.

In addition to the EO use, they have met the Teacher Portal (educational portal of Ministry of Education), where they have researched resources and pedagogical strategies available for the teaching of contents chosen and already inserted in the collectives Inclusive Teaching Plans (PEI). Besides this educational portal were suggested other research sources and the final product of this part of the Axis was the articulation of the contents worked. Based on reflections made during the previous virtual period, learners returned to the PEI and added the elements researched and used at this moment.

These research sources have articulated the knowledges on Inclusive and Special Education and about the ICDT use, in order to enhance teaching and allow a participative and constructionist dynamic. In accordance with Schlünzen [5], technology allows a new enchantment in school, enabling the emergence of students' interest, since they are natives in the technological age. It also creates the prospect of learning by playing, builds and expresses ideas creatively and, communicates.

Maybe this is the most important aspect to be considered, since with this resource the teacher could follow the student learning process, while it is happening and can intervene and reset it along with him. [5] (p. 81).

The research and collective construction generated comments in this direction, as explained by the group E, of the Campus of Presidente Prudente, when recognizing digital

3 The purpose of this Learning Object is to build a photo album, retrieving elements of students' experience and their history. 
educational resources for the work with their students:

The work with students with disabilities would enable, besides the individual work, for the students who could, also the interaction with colleagues that could for example, make the audio-description for students with visual impairment. (Group E, 12 Mar. 2012)

In that moment, learners also raised their concern of articulating the entire knowledge built in the Axis with the global work developed in school. The student M.E.L.S., also from Campus of Presidente Prudente, places her concern, in the Discussion Forum "arguing over the text 04 and elaboration of the Inclusive Education Plan":

To make more effective and meaningful the teacher's work, planning should be articulated to PPP, to students' needs and to what is expected. The assessment becomes then fundamental as a tool which shows the process to the teacher, where need to be changed and what is needed to ensure an inclusive education for all (M.E.L.S., 05 July 2012).

When pointing the evaluation and school planning, the learner brings important issues on teacher training to the center of discussions, is necessary to restructure the training process, which assumes the continuity characteristic. The teacher must be prepared to develop competences as being open to learn how to learn, assume an attitude of knowledge's investigator, propitiate reflection, debugging and thinking about the thinking. They should also dominate computational resources, identify application potentialities of these resources in the pedagogical practice, and develop a process of reflection and evaluation in practice and about the practice, in order to have elements to redesign continuously the theories, guiding his practice.

The fourth part of the Axis was drawn up in order to subsidize the development progress of the Inclusive Teaching Plan (PEI), which were developed over the previous weeks. The strategies and resources known in the previous activities were articulated to the contents proposed by the disciplines Content and Didactics of Mathematics and Physical Education. The contact and use of other EO in the construction and application of PEI was proposed again, based on the articulation of ideas for the use of these features in the face of distinct realities, presented by each member of groups already trained since the first week, considering their area of professional performance.

The student K.R.F., from the Campus of São José do Rio Preto, states that:

In addition to have, not only the need but also the obligation to work with different resources and materials with the students of inclusion, these additional devices also help in the education of students who do not have any deficiency, because it increases their understanding about the subject addressed, as in our project that utilized the audio description, which provides an idea of how are the video images to visually impaired and also increases the attention of other students in relation to descriptive details. (K.R.F., 19 Mar. 2012)

We noticed with that, the development of procedural contents established in the aims of the Axis, since, according to Zabala [7], the realization of the actions that make up the procedure or pedagogical strategy is the starting point that must be exercised multiple times to the reflection on the activity itself, in order to become aware of the performance. In addition, it is possible to realize that the new do of teacher has provided a teaching that might bring quality for all students of the class, covering the principle of school inclusion.

The orientation given was that the focus should be the learning of students, the development of his potential and abilities, within his context. It was also proposed the analysis of a video about an AEE project with students with high skills/giftedness, signaling for the reflection on specific needs of these EPAEE, since in the previous part they analyzed the EPAEE with global development disorders. The students had to articulate their knowledges and experiences for the elaboration of a PEI that valued human diversity and implement its practice application. This activity took place in the fifth part, after the disciplines Contents of Didactics of Geography, History and Sciences and Health.

In the final activities were clarified the creation elements of this space of analysis on the development and implementation of the Inclusive Teaching Plans (PEI) performed along the Axis. In this perspective, Morin [8] states that it is necessary to organize and reorganize the knowledge. This requires a reform of thinking, which not only allows isolating for knowing but, knowing to connect what is isolated, reviving global notions as the human being, the nature and the reality.

The first proposed activity was sharing the practical application results of PEI in the classroom or school. Learners had to highlight and register the positive work results, specifying actions and strategies that have helped to potentiate the students' learning, indicating also, the challenges faced in this process, difficulties encountered in the operationalization of the proposal and anxieties. Then, they elected, between the Inclusive Teaching Plans of the Group (applied individually), the one that would best represent the aspects highlighted for the poster presentation, guided by a specific roadmap, according to figure 2 . 


\title{
unesp

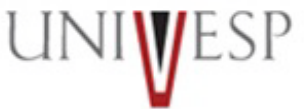

\section{Uma história, muitas histórias}

\author{
Rodrigo Carvalho, Saulo Ferreira, Thaís Blasio, Thais Borelli, Willian \\ Vinicius \\ EMEF Governador Mário Covas \\ $4^{a}$ Série \\ Campus São Paulo/ Polo Barra Funda
}

\begin{abstract}
PERFIL DOS ESTUDANTES
Foi escolhida para aplicação da atividade uma sala heterogênia de alunos com idades entre 9 e 10 anos. Todos os alunos encontravam-se alfabetizados, havendo, entretanto, alguns com pouca fluência na leitura. Na sala havia um aluno com deficiência intelectual e um menino cadeirante
\end{abstract}

\section{OBJETIVOS}

- Conhecer e ampliar seus conhecimentos em Informática, Língua Portuguesa e Artes de forma mais lúdica.

- Aumentar o gosto pela leitura e escrita

- Desenvolver a técnica do desenho para construção de um livro digital.

- Ampliar e articular os conhecimentos adquiridos até então.

- Promover uma maior socialização e participação dos alunos, deficientes ou não.

\section{RECURSOS UTILIZADOS}

Livro "O cachorro do menino", de César Obeid.

- Software "Flip book", disponível no site Benetton Play.

\section{ESTRATÉGIAS PEDAGÓGICAS}

- Contação de história

- Discussão coletiva dos conceitos: deficiência preconceito, intolerância e outros assuntos que poderão surgir.

- Reconto oral por parte das crianças da história.

- Rescrita da história.

- Caracterização pictórica dos personagens por cada aluno

- Uso de software educativo.

\section{ATIVIDADES DESENVOLVIDAS}

Apresentação (contação) da história "O cachorro do menino", de César Obeid.

Discussão com as crianças sobre a deficiência, preconceito, intolerância e outros assuntos que poderão surgir.

Reconto e reescrita da história pelas crianças: construção dos personagens por meio de desenhos.

Visita a sala de informática utilização do software "Flip book", disponível no site Benetton play, para concretização digital da narrativa recriada pelos alunos.

\section{RESULTADOS}

As atividades e resultados obtidos foram aquém de apenas Recontar ou desenhar...as discussões se pautaram nas relações entre os alunos, nas diferenças e no respeito á elas.

Os alunos recontaram a história com foco nos sentimentos e sensações provocadas pelo livro e ,mesmo que com a metáfora do cachorro, estabeleceram relações entre o livro e as situações vivenciadas na escola.

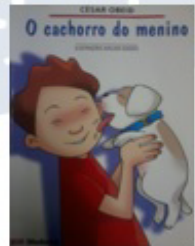

Figura 01: Livro utilizado Figura 02: nonononono

Figure 2. Final Poster prepared by students from the Campus São Paulo 3.

According to Zeichner [18] the teacher formation must work in his context, since, in addition to reflect about his practice, the teacher may also analyze the production conditions of his work (political, social and economic) that interfere directly in his practice, transforming the educative act in a social reflection.

The final moment of the discipline was drawn up in order to organize theoretical and practical elements presented, in a perspective of articulating the factual, conceptual, attitudinal and procedural contents, allowing the reflection over the action. Each activity carried out had as core, suggestions for their pedagogical practice, and the Final Memorial, contained the reflections about their role in the development of the PEI, as a contribution possibility to the construction of a more democratic and inclusive culture in the school space, meeting the learners' assumptions, as indicates R.C.S, Campus of Ourinhos:

The Inclusive Education requires of teacher an attitude change, in the sense of redefining his role, which is fundamental to the student's development: learn to respect their interests and to develop their activities: listening, formulating challenges and new situations, monitoring their development process. As to the school, it must adapt itself to students, always aiming the integration in society. At regular schools, to work with students with special educational needs in their regular education, teachers need adequate training. The great challenge of teachers is precisely to articulate what he has to teach with what the child has already built, with the student's learning way. (R.C.S., our emphasis) 
In accordance with Alarcão [19], teacher must reflect on his practice. This teacher, who reflects, thinks on what he does, is committed to his profession and meets the contexts in which he works, interprets and adapts them to his practice. The author warns that the educational contexts are extremely complex and there is no equal to another, in other words, training must stimulate the capacity to analyze, and these were the assumptions of the Articulating Axis proposed in this process of initial training in-service.

The methodological procedures used in the construction and implementation of the axis had as starting and arrival point the foundations of the Constructionist, Contextualized and Significant Approach (CCS) [5]. It allowed the verification that many reflections were made about the school resistances to changes required by the unconditional opening to human diversity and valorization of differences.

At the end of this construction, it was possible to create a space of analysis of the professional performance itself, using as starting point the CCS approach, and the use of ICDT, for the knowledge and detailing of Inclusive Education with a view toward EPAEE.

\section{Considerations}

The analysis on the development strategies of the Articulating Axis of Inclusive and Special Education compose the need for understanding the implications of this process of initial training in-service, in terms of the great themes: technologies, practices and inclusion. These themes are promoting great challenges of the inclusive school, tending to mobilize teachers and managers to review and recreate their role, through new practices starting from new educational possibilities. For this reason, besides addressing educational policies, we have presented several experiences using the Inclusive Teaching Plan (PEI) as a fundamental element in the teaching performance for a practice compromised with the construction of an inclusive school.

According with Santos [16], these actions promote reflection, where all participate and collaborate for the transformation of practice. Likewise, training no longer is mechanized since it goes through a prior planning that serves as roadmap, susceptible to changes at every intervention, each questioning, and every doubt.

The construction of knowledge along the Axis, in the face of these more than one thousand teachers in training, surely have already gained much more meaning for the students who are included in schools where these professionals act. These teachers, not only by this training process, but also through their own life experience, are already able to analyze with other viewpoints their practice, seeing some sense in the technology and its potential of accessibility and innovation and, glimpsing the inclusion with other perspectives based on the theoretical foundations addressed.

The possible formation of this network of knowledge and significations was thought as contraposition to curricula that value only content and the ready and finished truths, listed in serial school programs. For this reason, we seek to stimulate pedagogical strategies for the construction and integration of knowledges arising from the transversal curriculum, discovery, inventiveness and autonomy of learners in the conquest of knowledge built through the practice of elaboration, systematization and application of PEI.

Additionally, we sought to give a viewpoint on the role and importance of the articulation between Regular Teaching and AEE, whose purpose is to assist the teacher of regular class (target audience of this course) and the school, in the construction and fulfillment of the inclusive school. Our hope from this experience is that schools begin to develop strategies that enable them to offer an inclusive pedagogical organization, becoming polysemous environments [20], favored by study subjects starting from reality, of social and cultural identity of teachers, against all emphasis on content unrelated with social practice and against the emphasis on the knowledge by the knowledge. In other words, deconstruct the students' formation focused on school, focusing more on the use of disciplinary contents for their lives.

We finish this paper considering the salutary prospects of Mantoan [10], who points out that the essential is that all current and future investments of inclusive education recognize and value the differences in school. The challenges of initial teacher education in-service must be directly related to the quality level of school teaching that is required to have a school more than special, where the students have the right to be, being different.

\section{REFERENCES}

[1] NÓVOA, António Manuel Seixas de Sampaio da. Os professores e as histórias da sua vida (p.12). In: Nóvoa, A. (Org). Vidas de professores. Lisboa: Porto Editora, 1995.

[2] BRASIL. Ministério da Educação. Secretaria de Educação Especial. Política Nacional de Educação Especial na Perspectiva da Educação Inclusiva. Brasília: MEC/SEESP, 2007.

[3] HERNÁNDEZ, Fernando. Transgressão e mudança na educação: os projetos de trabalho. Porto Alegre: Artes Médicas, 1998

[4] SÃO PAULO. Universidade Estadual Paulista "Júlio de Mesquita Filho". Plano de Desenvolvimento Institucional (p.1). São Paulo: Reitoria. Available at: https://ape.unesp.br/pdi/execucao/index.php, accessed on 25 July 2013.

[5] SCHLÜNZEN, Elisa Tomoe Moriya. Mudanças nas práticas pedagógicas do professor: criando um ambiente construcionista contextualizado e significativo para crianças com necessidades especiais físicas. São Paulo, 2000. Tese (Doutorado em Educação: Currículo) - PUC-SP, 2000.

[6] VALENTE, José Armando. O papel da mediação e da interação na educação a distância: estabelecendo estratégias 
diferenciadas de ensino. In: TRINDADE, Maria Angela Bianconcini (org). As tecnologias de informação e comunicação (TIC) no Desenvolvimento de Profissionais do Sistema Único de Saúde (SUS). São Paulo: Instituto de Saúde, 2011.

[7] ZABALA, Antoni. A prática educativa. Porto Alegre: Artmed, 1998.

[8] MORIN, Edgar. A cabeça bem-feita: repensar a reforma, reformar o pensamento (p.13). Edgar Morin; trad. Eloá Jacobina. 20 a ed. Rio de Janeiro: Bertrand Brasil, 2012.

[9] SÃO PAULO. Universidade Estadual Paulista "Júlio de Mesquita Filho". Curso de Pedagogia Projeto do Curso Ementas e Grade - Parte 1 (2008). São Paulo: Reitoria. Available at: http://edutec.unesp.br/images/portal/ementas/completo1.pdf, accessed on 25 July 2013.

[10] MANTOAN, Maria Teresa Egler. O direito de ser, sendo diferente, na escola. In: RODRIGUES, D. Inclusão e Educação: Doze Olhares sobre a Educação Inclusiva. São Paulo: Summus, 2004.

[11] BRASIL. Ministério da Educação. Secretaria de Educação Especial. Diretrizes Nacionais para a Educação Especial na Educação Básica. Brasília: MEC/SEESP, 2003.

[12] BRASIL. Ministério da Educação. Lei de Diretrizes e Bases da
Educação Nacional. LDB 9.394, de 20 de dezembro de 1996.

[13] BRASIL. Assembléia Nacional Constituinte. Constituição da República Federativa do Brasil. Brasília: Senado Federal / Secretaria Especial de Editorações e Publicações, 1988.

[14] BRASIL. Ministério da Educação. Resolução CNE/CEB nº 2 , de 11 de setembro de 2001 .

[15] DELORS, Jacques (org.). Educação: um tesouro a descobrir. 3 ed. São Paulo: Cortez. Brasília, DF. MEC: UNESCO, 1999.

[16] SANTOS, Danielle Aparecida do Nascimento dos. A formação de professores de uma escola da rede pública estadual em serviço para o trabalho com projetos usando as Tecnologias de Informação em Comunicação. Presidente Prudente, 2007. Dissertação (Mestrado em Educação) FCT/Unesp, 2007.

[17] ZEICHNER, Kenneth M. A Formação Reflexiva de Professores, Idéias e Práticas. EDUCA, Lisboa, 1993.

[18] ALARCÃO, Isabel. Refletir na Prática. Nova Escola On-line Fala, mestre! Edição No 154. Agosto 2002. Available at: novaescola.abril.com.br/index.htm?ed/154_ago02/html/fala mestre, accessed on 25 Jan. 2007.

[19] GALLO, Sílvio. Transversalidade e educação: pensando uma educação não-disciplinar. In: ALVES, Nilda e GARCIA, Regina Leite (Orgs.). O sentido da escola. Rio de Janeiro: DP\&A, 1999. 